
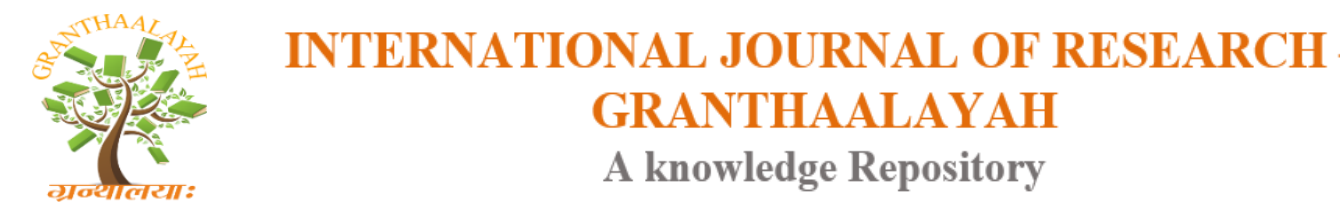

Science

\title{
COMPREHENSIVE EFFORTS SEED QUALITY IMPROVEMENT OF SUGARCANE (SACCHARUMOFFICINARUM L.) THROUGH A SINGLE METHOD BUD PLANTING A GARDEN SEEDS AND PLANTING MATERIAL
}

\author{
Endang Suhesti ${ }^{* 1,2}$, Eko Widaryanto ${ }^{3}$, Budi Waluyoh ${ }^{3}$, Sri Winarsih 4 \\ ${ }^{*}$ Graduate School of Agriculture School of Agriculture, Faculty of Agriculture, Brawijaya \\ University, Malang, Indonesia \\ ${ }^{2}$ Faculty of Agriculture, University of Abdurachman Saleh, Situbondo, Indonesia \\ ${ }^{3}$ Faculty of Agriculture, Brawijaya University, Malang, Indonesia \\ ${ }^{4}$ Staff researcher at the Indonesian Sugar Plantation Research Center (ISPR) Pasuruan,
} Indonesia

\begin{abstract}
The study was designed to improve the quality of the SBP as milled cane planting material by improving the early growth of plants. Research carried out gradually implemented in the Indonesian Sugar Plantation Research Center (P3GI) Pasuruan, using two varieties of sugarcane are varieties Bululawang and PS 862 with numbers 7-16 buds. Germination (\%), was observed on the 15th day after planting (DAP) and the growth of the plant include: plant height, number of leaves, leaf area, as well as the production of biomass include: Dry weight (DW) and fresh weight (FW) plant organs (leaves, stems, and roots). Fresh Weight (BS) and Dry Weight (BK) total crop. The results showed the top eye numbers $(7,8,9,10)$ for both varieties provide the same germination potential $(>70 \%)$. But the number of buds bottom $(11,12,13,14,15,16)$ Bululawang varieties give a lower percent germination than varieties of PS 862. At PS 862 varieties buds numbers 8 and 9 can generate over 95 percent germination \%. Number eye affects plant growth in polybag components which include plant height, leaf area and the number of leaves and observation of the biomass production shows the influence of the number of eyes. These parameters indicate a decrease in the number and size of the eyes of the lower numbers. While the diameter rod eye development is not affected numbers. PS 862 varieties showed faster growth than Bululawang varieties. However, exposure to biomass production, Bululawang varieties showed higher yields than at PS 862 varieties.
\end{abstract}

Keywords: Single Bud Planting; Eye Number; Germination; Vegetative Growth.

Cite This Article: Endang Suhesti, Eko Widaryanto, Budi Waluyoh, and Sri Winarsih. (2018). "COMPREHENSIVE EFFORTS SEED QUALITY IMPROVEMENT OF SUGARCANE (SACCHARUMOFFICINARUM L.) THROUGH A SINGLE METHOD BUD PLANTING A GARDEN SEEDS AND PLANTING MATERIAL." International Journal of Research Granthaalayah, 6(4), 111-120. https://doi.org/10.29121/granthaalayah.v6.i4.2018.1486. 


\section{Introduction}

Sugar is one of the strategic commodities in Indonesia's economy. One cause of the low production of sugar cane including seed preparation, seed quality and fewer cane availability of land for seeding. We have been developed seed cane derived from the buds or the popular so-called single bud planting (SBP). The advantages of the SBP is having the ability to grow uniformly, the number of seedlings produced more than conventional seeding system, higher seed between 20-25 (in 1 ha of seed stands when made SBP then be embedded within 20-25 ha of sugarcane milled), save space in the seeding process (Litbang Induk PTPN XI, 2013).

In sugarcane buds numbers affect the germination, the usage buds appropriate number is expected to generate plants with good growth and production (Pujiarso, 2003). Cuttings are derived from the crown generally faster germination compared with cuttings underneath it. In addition to a number of eyes, important factors that affect the germination of varieties. The major difference occurs in different sugarcane varieties in the process of germination. In sugarcane varieties determine the size of the crop to be achieved so that the varieties chosen should have the properties of high production, cultivation treatment resistant, drought resistant, resistant must be cut, have a high growth rate and resistance to pests and diseases.

\section{Materials and Methods}

\subsection{Of sprouts power}

Experiments in the bed aim to find numbers buds showed the best growth in two sugarcane varieties that $\mathrm{V} 1=\mathrm{V} 2=$ varieties and varieties Bululawang PS 862. This experiment was designed using a split-plot design consisting of two factors and repeated 3 times. The main plot is composed of two varieties of treatment that Bululawang and PS 862. The subplots were buds number consists of 10 treatments, eye number 7 to number 16. Observations of percent germination experiments performed on each plot begin 3 days after planting (DAP) up to 15 DAP.

\subsection{Plant growth}

Experiment to II aims to see the best growth of 10 numbers buds of two different varieties of sugarcane crop in polybags. Observations sugarcane is non-destructive and destructive. Nondestructive observations performed at the age of 30 plants, 60 and 90 days after planting while destructive observations made at the end of 90 DAP observations. Observation of plant growth includes plant height, number of leaves, leaf area, stem diameter. Observation of the production of biomass includes Dry weights (DW) and fresh weight (FW) plant organs (leaves, stems, and roots). Fresh Weight (FW) and Dry Weight (DW) total crop.

\subsection{Data analysis}

Statistical analysis was performed with the aid of DSAASTAT device to test the effect of treatment. The analysis was performed on all variables observed data. The average difference of treatment based on the test Tukey (HSD) at a significance level of 5 percent (\%).

\section{Results and Discussion}




\subsection{Results}

The results showed that the number of eyes gives effect to the percent germination. Both varieties also influence significantly towards viability (Table 1).

Table 1 Interaction Varieties and Number Mata against Percent Germination at age showed that the number of eyes gives effect to the percent germination. Both varieties also influence significantly towards viability (Table 1).

Table 1: Interaction of Varieties and Eye Numbers on Germination Percentage at Age of Observation 15 DAP

\begin{tabular}{|c|c|c|c|c|c|c|c|c|c|c|c|c|c|c|c|}
\hline \multirow[b]{3}{*}{ Varieties } & \multicolumn{15}{|c|}{ Germination (\%) } \\
\hline & \multicolumn{15}{|c|}{ Eye Numbers } \\
\hline & \multicolumn{2}{|c|}{7} & \multirow{2}{*}{$\frac{8}{82,48}$} & & \multicolumn{2}{|c|}{9} & \multicolumn{2}{|c|}{10} & \multirow{2}{*}{$\frac{11}{60,77 b c}$} & \multirow{2}{*}{$\frac{12}{53,97 b c}$} & \multirow{2}{*}{$\frac{13}{51,43 b c}$} & \multirow{2}{*}{$\frac{14}{45,10 c}$} & \multirow{2}{*}{$\frac{15}{43,40 c}$} & \multicolumn{2}{|c|}{16} \\
\hline \multirow[t]{2}{*}{ Bululaw ang } & 80,20 & a & & a & 82,47 & a & 70,41 & $a b$ & & & & & & 43,36 & c \\
\hline & \multicolumn{2}{|c|}{ A } & A & & \multicolumn{2}{|c|}{ A } & \multicolumn{2}{|c|}{ A } & B & B & B & B & B & B & \\
\hline \multirow[t]{2}{*}{ PS 862} & 85,74 & abcd & 96,90 & a & 95,39 & $a b$ & 89,71 & $a b c$ & $86,35 \mathrm{abcd}$ & $84,28 \mathrm{abcd}$ & 81,57 abcd & $76,80 \mathrm{bcd}$ & $75,00 \mathrm{~cd}$ & 70,23 & d \\
\hline & $\underline{A}$ & $A$ & $\mathrm{~A}$ & & A & & A & & A & A & A & A & A & A & \\
\hline HSD 5\% & \multicolumn{15}{|c|}{21,91} \\
\hline
\end{tabular}

Description: The average value followed by the same lowercase letters in the same row showed no significantly different according to HSD test at 5\% level; The average value followed by the same capital letter in the same column showed no significantly different according to HSD test at 5\% level, DAP: Day After Planting.

Table 1 shows the interaction between the variety and number of buds. Bululawang varieties buds on number 7. 8, 9 and 10 resulted in percent germination were not significantly different, the fourth buds produce better germination compared with the number of other buds. Bud's upper part (7, 8, $9,10,11,12$ and 13) resulted in higher germination percent compared with the number of buds lower part (14, 15 and 16).

At PS 862 percent varieties buds germination at number 7 to 13 resulted in percent germination were not significantly different. Germination percentage on the number upper eyes (buds at numbers $7,8,9,10,11,12$, and 13) gives a higher yield when compared with the number of the lower eye (14.15 dan16).

The relationship between the number of buds with the percent germination at Bululawang varieties formulated in a linear equation $\mathrm{Y}=121.00-5,19 \mathrm{X}$ with $\mathrm{R} 2=0,927$. Pada PS 862 varieties formulated with linear equation $\mathrm{Y}=112.93$ - 2,50X with R2 0.77 . From number R2, it can be argued that the relationship between the eyes with the percent germination numbers very closely on both varieties. 


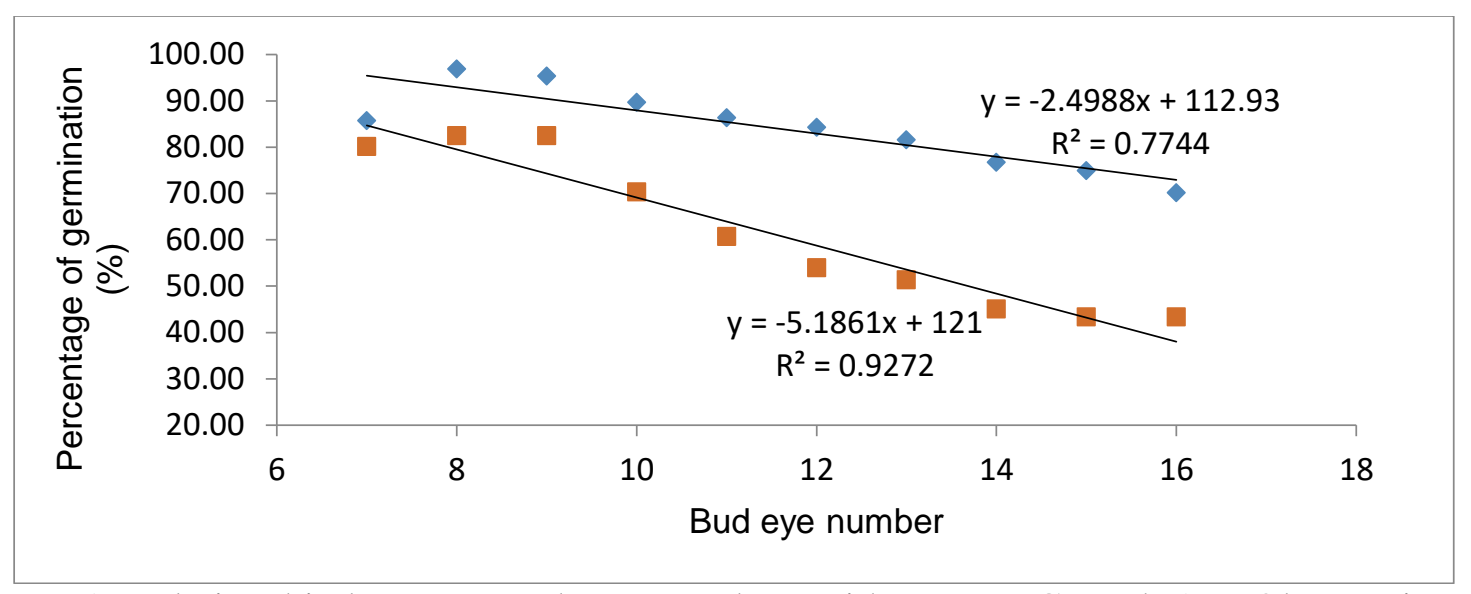

Figure 1: Relationship between Bud Eye Numbers with Percent Growth Age Observation 15 DAP

The result of variation analysis on observation parameters of plant height showed there was interaction between plant height with eye bud number at age of 90 DAP observation.

\begin{tabular}{|c|c|c|c|c|c|c|c|c|c|c|c|}
\hline \multirow{3}{*}{$\begin{array}{c}\text { Treatment } \\
\text { Varieties } \\
\end{array}$} & \multicolumn{11}{|c|}{ Interaction of varieties and eye numbers } \\
\hline & \multicolumn{11}{|c|}{ Eye Numbers } \\
\hline & 7 & 8 & 9 & 10 & 11 & 12 & 13 & & 14 & 15 & 16 \\
\hline \multirow[t]{2}{*}{ Bululaw ang } & $134,00 a$ & $130,50 a$ & $127,50 \mathrm{ab}$ & $120,33 \mathrm{bc}$ & $115,33 \mathrm{~cd}$ & $114,67 \mathrm{~cd}$ & 119,00 & bed & $109,67 \mathrm{~d}$ & $115,25 \mathrm{~cd}$ & $116,00 \mathrm{~cd}$ \\
\hline & A & A & A & A & A & A & A & & A & A & A \\
\hline \multirow[t]{2}{*}{ PS 862} & 118,50 a & 118,00 a & 118,50 a & 114,50 a & 112,33 a & 118,00 a & 117,00 & a & $117,00 a$ & 115,00 a & 119,50 a \\
\hline & B & B & A & A & A & A & A & & A & A & A \\
\hline HSD 5\% & \multicolumn{11}{|c|}{9,83} \\
\hline & & & & & & & & & & & \\
\hline
\end{tabular}

Description: The average value followed by the same lowercase letters in the same row showed no significantly different according to HSD test at 5\% level; The average value of which followed the same capitalization in the same column showed no significantly different according to test HSD at the level of 5\%, DAP: Day After Planting.

The variable height of plant varieties Bululawang with age observations 90 HST show the differences are not real at number eyes shoots 7,8 , and 9 . number buds 7 showed the fastest growth, followed by the number of buds 8 and 9 . While plant height at eye number 14 gives the lowest value. At PS 862 varieties of high yielding crops which were not significantly different in all the numbers buds.

Overall Bululawang varieties do not give a real difference to the speed of growth when compared to PS 862 varieties except in the eyes of numbers 7 and 8 where the variety Bululawang showing faster growth compared to the varieties 862 .

\section{Stem Diameter}

At the age of 90 HST plant varieties and numbers, eyes showed no interaction. In the single factor does not show any difference to a stem diameter at the eyes of all varieties and numbers. 


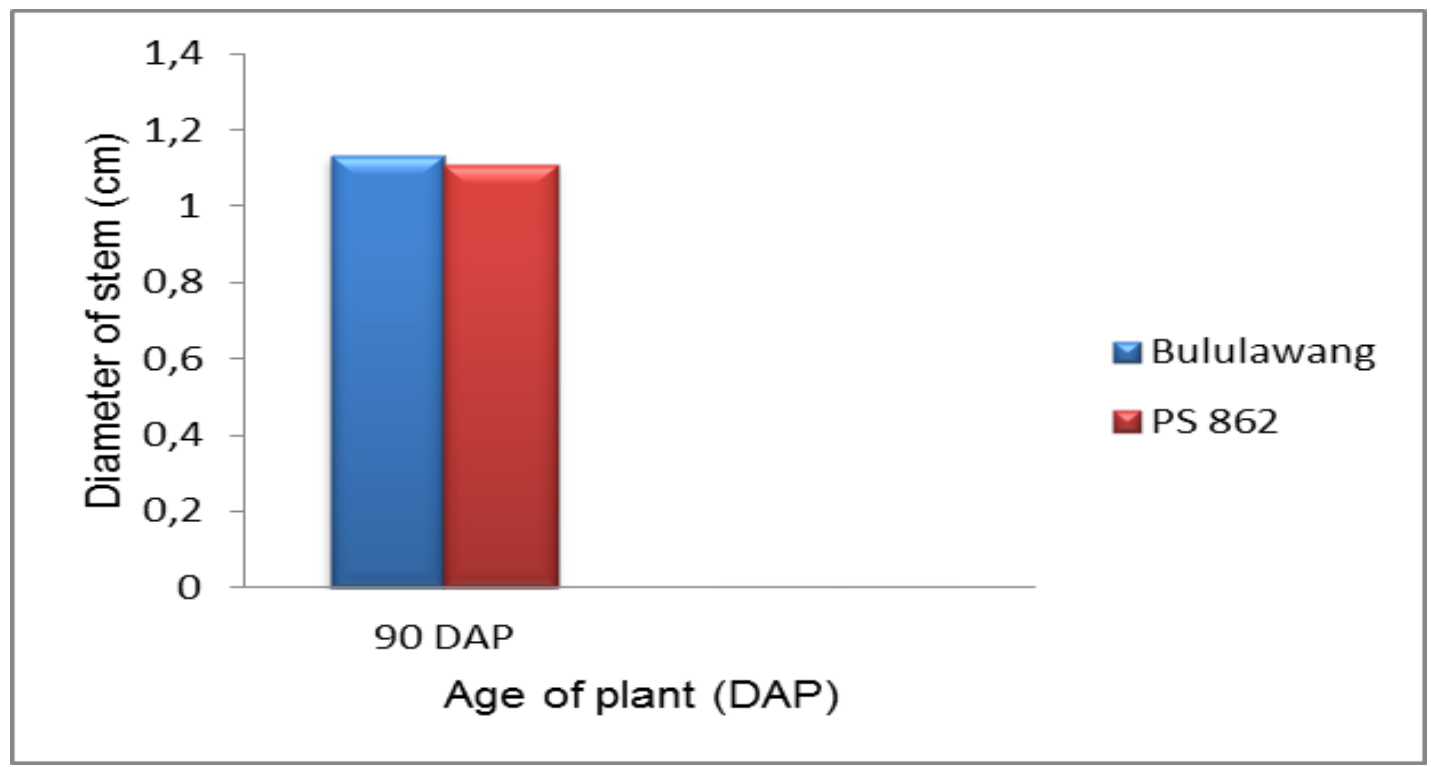

Figure 2: Diameter in Two Varieties of Sugarcane Age 90 DAP observations

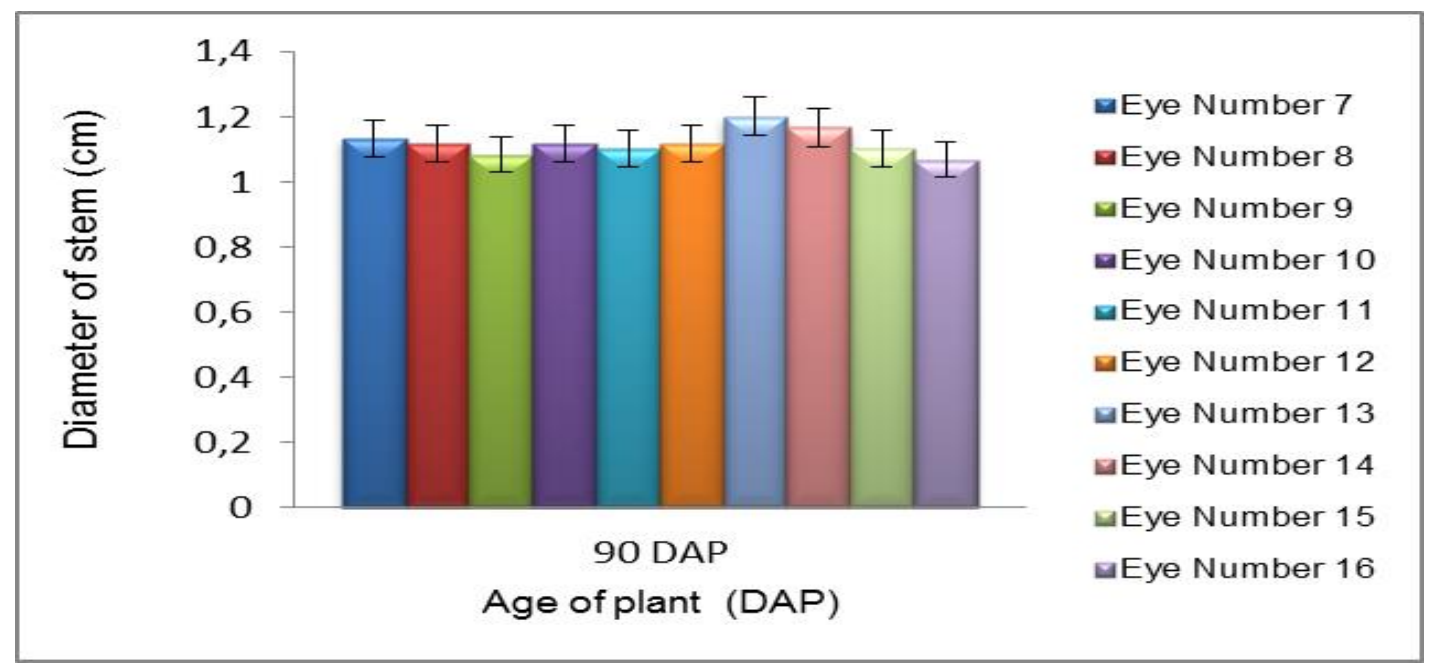

Figure 3: Bar Trunk at Treatment Number Eye Age Observation 90 DAP

\section{Weight Total Plant per a clump of}

Results of analysis of variance showed the fresh weight of total crop value there is the interaction between varieties with the number of buds at the age of 90 HST observations. Varieties Bululawang buds numbers 7, 8, and 9 were not significantly different and higher than the number of other buds. While the number of buds 14 giving the lowest result of the fresh weight of the total crop, not significantly different from the number of buds 16. At PS 862 varieties, eye numbers 7, 8,9 and 12 show the value of the total fresh weight of the plants were not significantly different and higher compared to the number of another eye. The total fresh weight of plant buds highest at number 7 and the lowest buds number 15, while the value of the total fresh weight of plant varieties Bululawang greater than or equal to the varieties of PS 862. 
Table 3: The interaction between Variety and Number Mata shoots towards Parameter Weights Fresh total Plant clumps-1 at age 90 DAP observations

\begin{tabular}{|c|c|c|c|c|c|c|c|c|c|c|c|c|c|}
\hline \multirow[b]{3}{*}{ Treatment } & \multicolumn{13}{|c|}{ Total Fresh Weight ( gram clumps ${ }^{-1}$ ) } \\
\hline & \multicolumn{13}{|c|}{ Eye Numbers } \\
\hline & 7 & 8 & & 9 & & 10 & 11 & 12 & & 13 & 14 & 15 & \\
\hline \multirow[t]{2}{*}{ Bululaw ang } & 92,18 a & 85,85 & $a b c$ & 87,91 & $a b$ & $69,3 \mathrm{cde}$ & 69,75 cde & 81,02 & bcd & $73,53 \mathrm{~cd}$ & $61,57 \mathrm{e}$ & $76,2 \mathrm{bcd}$ & 61,6 \\
\hline & A & A & & A & & A & A & A & A & A & A & A & A \\
\hline \multirow[t]{2}{*}{ PS 862} & 73,51 a & 71,86 & $a b c$ & 68,38 & bc & $65,04 \mathrm{bcd}$ & 69,01 bc & 65,06 & bcd & 61,93 de & $65,25 \mathrm{bcd}$ & 57,51 e & 63,25 \\
\hline & B & B & & $\mathrm{B}$ & & A & A & B & 3 & $\mathrm{~B}$ & A & B & $\mathrm{A}$ \\
\hline HSD $5 \%$ & \multicolumn{13}{|c|}{8,92} \\
\hline & & & & & & & & & & & & & \\
\hline
\end{tabular}

Description: the average value followed by the same lowercase letters in the same row showed no significantly different according to HSD test at 5\% level; The average value of which followed the same capitalization in the same column showed no significantly different according to test HSD at the level of 5\%, DAP: Day After Planting.

The results of analysis of variance showed the interaction between varieties with the number of buds on the parameters of the dry weight of the total age of observation 90 HST. Varieties buds Bululawang with numbers $7,8,9,1,13$ and 15 did not differ significantly, but significantly different from the value of the total dry weight of the plant buds numbers 10, 11, 14 and 16 .

No. buds 7, 8, 9, 10 and 11 on the varieties of the PS 862 provides total dry weight of the plant were not significantly different, but significantly different to the value of total dry weight of the plant number buds $10,12,13,14,15$ and 16, the whole value of the total dry weight of plant varieties Bululawang not significantly different from PS 862 varieties buds except the numbers 12 and 13 where the variety Bululawang give a total dry weight values were higher than Bululawang varieties.

Table 4: The interaction between Variety and Number Mata shoots towards Parameter Dry Weight Total Plant clumps-1 at age 90 HST observations

\begin{tabular}{|c|c|c|c|c|c|c|c|c|c|c|}
\hline \multirow[b]{3}{*}{ Treatment } & \multicolumn{10}{|c|}{ Total dry weight of the plant } \\
\hline & \multicolumn{10}{|c|}{ Bud eye number } \\
\hline & 7 & 8 & 9 & 10 & 11 & 12 & 13 & 14 & 15 & 16 \\
\hline \multirow[t]{2}{*}{ Bululaw ang } & 18,95 at & $18,17 \mathrm{ab}$ & 20,97 & 16,12 bcd & $16,13 \mathrm{bcd}$ & 20,06 a & $18,58 a b$ & $14,96 \mathrm{~d}$ & $17,11 \mathrm{bc}$ & $14,33 \mathrm{c}$ \\
\hline & A & A & A & A & A & A & A & A & A & A \\
\hline \multirow[t]{2}{*}{ PS 862} & $20,44 a$ & $19,49 a b$ & 20,45 & $16,63 \mathrm{bcd}$ & $18,43 \mathrm{abc}$ & $14,2 \mathrm{~cd}$ & $14,84 \mathrm{~cd}$ & $15,02 \mathrm{~cd}$ & $15,55 \mathrm{~cd}$ & 12,56 \\
\hline & B & B & B & A & A & B & B & A & B & A \\
\hline HSD $5 \%$ & \multicolumn{10}{|c|}{5,22} \\
\hline & & & & & & & & & & \\
\hline
\end{tabular}

Description: The average value followed by the same lowercase letters in the same row showed no significantly different according to HSD test at level 5\%; The average value followed by the same capital letter in the same column showed no significantly different according to HSD test at 5\% level, DAP: Day After Planting. 


\subsection{Discussion}

On top eye numbers $(7,8,9,10)$ for both varieties provide the same germination potential $(>70 \%)$. But the number of buds bottom $(11,12,13,14,15,16)$ Bululawang varieties give a lower percent germination than varieties of PS 862. At PS 862 varieties buds numbers 8 and 9 can generate over 95 percent germination $\%$. Sugarcane single currency that germinated individually in polybags able to produce excellent germination percent (> 95\%) with normal early growth of seedlings (Jain et al.,2010).

Relations between the eyes with the percent germination number on both varieties are very close. The larger the number the eyes (near the base), the percent germination decreases. One factor to consider in germination is the germination gradient is a change in the amount of increase or decrease in the ability to germinate eye on cane segments with respect to its location along the stem of sugarcane. The layout of the eyes on sugarcane stem segments showing its age. Age eye on the bottom rod segment is older than the eyes that were on the road towards the end of the rod.

Differences result a very large germination can occur on different varieties of sugarcane. Bululawang varieties are classified as slow cooking show lower percent germination on rootstock varieties compared to PS 862. Based on these results, the eye numbers from 7 to 13 can be selected as planting material, eye number 7 is not used because it has a soft rod for use as planting material commercially.

Cuttings from the top of the rod that has been cooked, germinate more quickly and have a high growth percentage compared to the trunk bottom (Abayomi et al.,1990). This is because food reserves rod lower part is stored in the form of sucrose, while the germination process takes glucose so that the eyes are located at the bottom still need time to break down sucrose into glucose and vice versa shoot cuttings contain a lot of glucose and water so quickly germinate, but if not will germinate quickly perishable. Sucrose and glucose levels sugarcane varieties Bululawang and PS 862 can be seen in the image below.

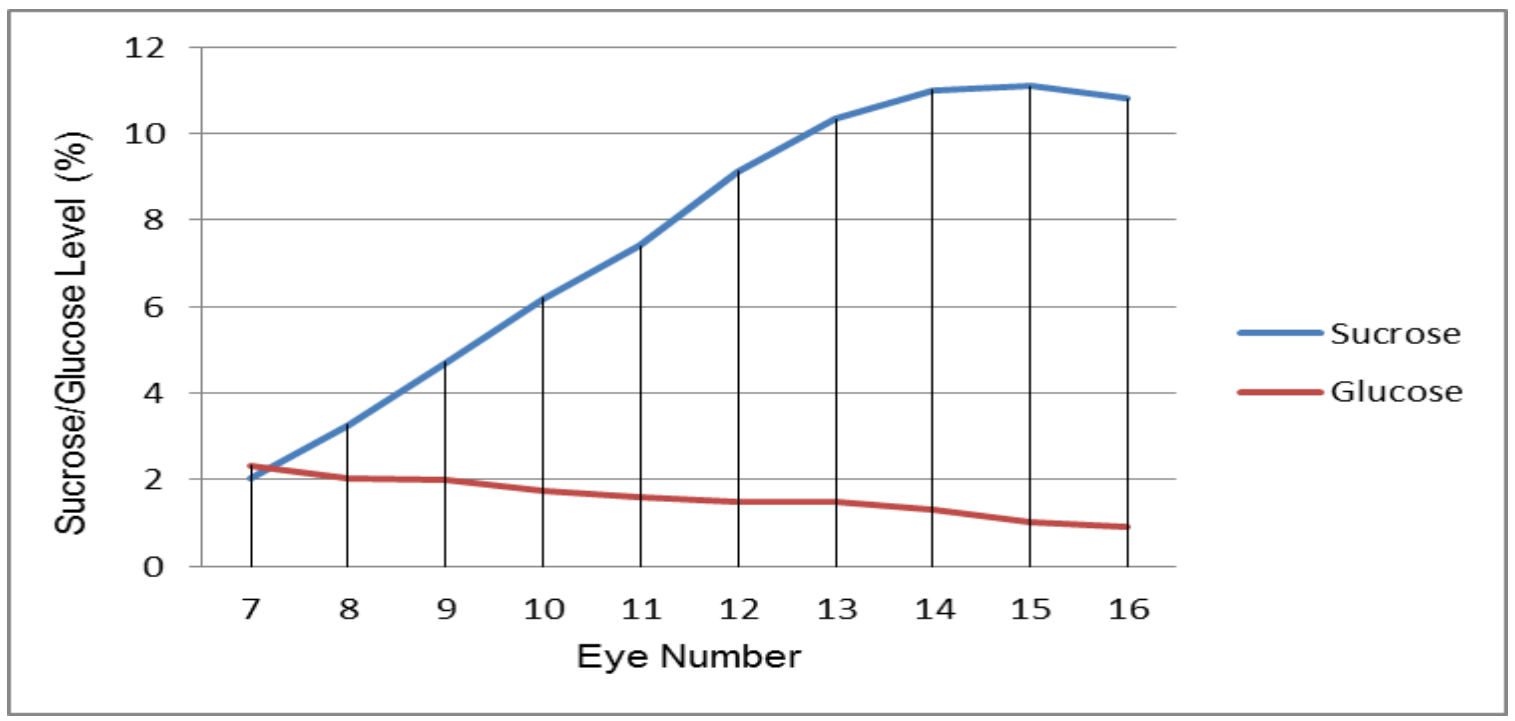

Figure 4: Levels of sucrose and glucose is Sugarcane Variety Bululawang 


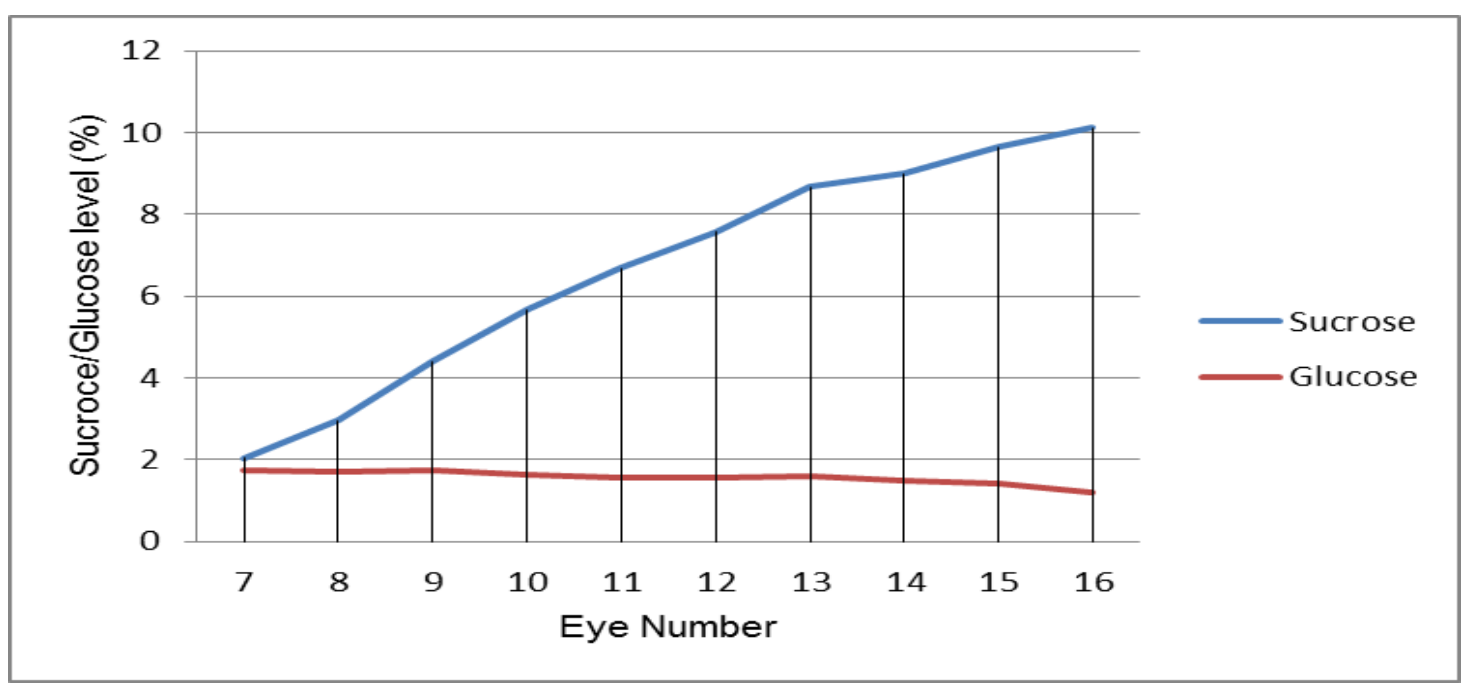

Figure 5: Levels of sucrose and glucose is Sugarcane Variety PS 862

In the second chart above shows that at the base of the stem high levels of sucrose so it takes time to break down sucrose into glucose. In the eyes of varieties Bululawang the bottom number had decreased levels of sucrose and glucose so that the eye numbers 14,15 and 16 percent germination and germination speed index also began to decline. But at PS 862 varieties still decreased levels of sucrose and glucose so that the percent germination and germination speed index number bud eye on the bottom is higher than the Bululawang varieties.

Note that fhase plant growth in the germination process is also highly dependent on the availability of water and food contained in the buds. Seeds with poor quality, for example, obtained from the seeds old age the conditions of distribution of water and nutrients in the body tissues shoots will complicate the already reduced initiation sprout.

Variable percent germination in two varieties showed high results at the number on until the middle of the eye. Stem top has better growth because the top has a younger shoot so the content auxin more. Auxin on sugarcane serves to stimulate cell elongation and enlargement. Rod's bottom shows lower growth than the upper and middle trunk. This is due in addition to the low auxin content was also caused by high levels of sucrose in the stem bottom. High sucrose content of which would inhibit the germination of buds for sucrose in the process should be reformed into simple sugars are glucose to be used as a food reserve.

Plant height is an indicator of growth as well as the parameters used to measure and determine the effect of the treatment used in experiments or as an indicator to determine the effect of the environment. THeigh plants show their interaction with eye number. In varieties, Bululawang number of young shoots $(7,8,9,10,11,13)$ in the form of high yield plant grow faster. While the PS 862 varieties all buds produce high numbers of plants are not significantly different. All eyes on the number PS 862 varieties have the same growth rate resulting in up to 16 eye numbers can still be used as a seed orchard planting material. This is consistent with agronomic properties owned by PS 862 varieties which buds germination is very easy and fast growing in unison.

In the cultivation of sugar cane, a major part of most plants stems. In addition to plant height, stem parts that can be observed are the diameter of the rod. In the variable stem, diameter showed no 
difference in the two varieties and all eyes numbers. This is consistent with the description of the two varieties have medium to large diameter trunk.

Plant growth can be observed through the fresh weight of the total crop. While the total dry weight of plants can be observed as plant growth are closely linked to the fresh weight of the total crop. Varieties Bululawang on the total fresh weight of the plant gives a higher value when compared to varieties of the PS 862. At Bululawang varieties increase total plant dry weight was higher when compared to the PS 862. variety Bululawang varieties have properties that are able to adapt more widely so aimlessly growth higher and ultimately the total dry weight of the resulting plants are also higher. There is the same tendency in both the measured parameters in which the value of the fresh and dry weight of the total crop decreases in numbers approaching the base of the eye. This will affect also to harvest. Yields are influenced by the production of biomass produced during the vegetative total dry weight of plants produced. According to Sitompul and Guritno (1995), that one of the factors that determine the growth of crop plants is the production of plant biomass in addition to genetic factors and the allocation to the harvested fotosintat.

\section{Conclusions}

Number eye has a close relationship with germination. Getting closer to the base of the decline of the germination. In the eyes of varieties, Bululawang numbers 8 through 13 can be used as seed planting material. At PS 862 varieties all his numbers (8-16) can be used as a seed orchard planting material. PS 862 varieties higher in yield germination (> 70\%) when compared to varieties Bululawang.

Number eye affect plant growth components include plant height, stem diameter, and biomass production. These variables showed a decrease in the number and size of the eyes of the lower numbers. While the diameter rod eye development is not affected numbers. PS 862 varieties showed faster growth than Bululawang varieties. However, exposure to biomass production, Bululawang varieties showed higher yield than the varieties of PS 862 .

\section{Acknowledgment}

Thanks to the family who has provided support both morally and materially for my success. Thank you also to my friends for togetherness all this time. Finally, thank you for all of you.

\section{References}

[1] Abayomi, Y.A, Etejere, E.O and Fadayomi, O. 1990. Effect of Stalk Section, Coverage Depth and Date of First Irrigation on Seedcane Germination of Two Comercial Sugarcane Cultivars in Nigeria. Turrialba 40 (1): 58-62.

[2] Aji, P. 2011. Optimalisasi Teknik Budidaya Untuk Setiap Fase Kehidupan Tanaman Tebu. Clements, H. F. 1980. Sugarcane crop logging and crop control: Principles and practices.520. The University Press of Hawaii: Honolulu.

[3] Gardner, F.P., R.B. Pearce, dan R.L. Mitchell. 1991. Physiology of Crop Plants. Terjemahan Fisiologi Tanaman Budidaya. UI Press. Jakarta.

[4] Gujja, B., Loganandhan N., V. Vinoud G., Manisha A., Sashi B., dan Alwara S. 2009. Sustainable Sugarcane Initiative: Improving Sugarcane Cultivation in India. Icrishat, Patancheru 
[5] Kuntohartono, T. 1999. Pertunasan Tanaman Tebu. Gula Indonesia.24 (3): 11-15.Lo, C.S \& C.Y.Lin. 2002. Screeningstrains of Trichoderma spp forplant growth enchament inTaiwan. Plant Pathology Bullettin 11: 215-220.

[6] Litbang Induk PTPN XI. 2013. Single Bud Planting (Model Cenicana Columbia), Politeknik Negeri Jember.

[7] Lingle, S. E. 1997. Seasonal internode development and sugar metabolism in sugarcane. Crop Sci. 37:1222-1227

[8] Sitompul, SM. Dan B. Guritno. 1995. Analisis pertumbuhan tanaman. Gajah Mada Univ. Press. Yogyakarta.

[9] Srinivasan, T. R. 1995. Crop production technologies: I. In Sugarcane Production manual. 2642. Sugarcane Breeding Institute, Coimbatore.

[10] Sundara, B. 1998. Sugarcane Cultivation. First Edition. Vikas Publishing House Pvt Ltd. New Delphi.p.33-44.

*Corresponding author.

E-mail address: laurensiusl@ yahoo.co.id 